\title{
PENERAPAN MODEL DISCOVERY LEARNING DENGAN PENDEKATAN SAINTIFIK UNTUK MENINGKATKAN HASIL BELAJAR MATEMATIKA SISWA KELAS VII 6 SMP N 01 KOTA BENGKULU
}

\author{
Arif Rahmad Julian, Hanifah, Nurul Astuty Yensi B \\ Universitas Bengkulu, FKIP, Program Studi Pendidikan Matematika \\ email : arif.rahmad33@gmail.com, ${ }^{2}$ hanifah@unib.ac.id, ${ }^{3}$ nurulastutyyensy@yahoo.com
}

\begin{abstract}
Abstrak
Penelitian ini bertujuan untuk meningkatkan hasil belajar siswa kelas VII 6 SMP Negeri 01 Kota Bengkulu dalam pembelajaran matematika melalui model pembelajaran Discovery Learning dengan pendekatan Saintifik. Jenis penelitian ini adalah Penelitian Tindakan Kelas (PTK). Subjek penelitian ini adalah siswa kelas VII 6 SMP Negeri 01 Kota Bengkulu yang berjumlah 33 siswa yang terdiri dari 19 siswa perempuan dan 14 siswa laki-laki. Instrumen pengumpulan data yang digunakan dalam penelitian ini adalah lembar tes. Hasil belajar siswa dikatakan berhasil apabila rata-rata hasil belajar siswa mencapai $\geq 80$ dan persentase ketuntasan belajar siswa $\geq 80 \%$. Hasil penelitian menunjukkan bahwa model pembelajaran Discovery Learning dengan pendekatan Saintifik yang dilaksanakan dengan membagikan LKPD dengan tahapan Discovery Learning yaitu tahapan stimulasi, identifikasi masalah, mengumpulkan data dan mengolah data, verifikasi, dan mengorganisasikan dengan digabungkan pendekatan Saintifik yaitu mengamati, menanya, mengumpulkan informasi, mengasosiasi dan mengomunikasi dapat meningkatkan hasil belajar siswa kelas VII 6 SMP Negeri 01 Kota Bengkulu. Hal tersebut terbukti dengan adanya peningkatan nilai ketuntasan klasikal pada siklus I, II dan III secara berturut-turut adalah $69,69 \%$; 78,78\% dan $84,84 \%$.
\end{abstract}

Kata kunci : Hasil Belajar, Pembelajaran Discovery Learning, Pendekatan Saintifik.

\begin{abstract}
The objectives of this research were to improve student learning outcomes of class VII 6 of SMP Negeri 01 Bengkulu City in learning mathematics through Discovery Learning learning model with a scientific approach. This type of research was Classroom Action Research (CAR). The subjects of this study were students of class VII 6 of SMP Negeri 01 Bengkulu City, totaling 33 students consisting of 19 female students and 14 male students. The data collection instrument used in this study is a test sheet. Students 'learning outcomes were said to be successful if the average student learning outcomes reach $\geq 80$ and the percentage of students' learning mastery $\geq 80 \%$. The results showed that the learning model of Discovery Learning with scientific approach implemented by distributing LKPD with the stages of Discovery Learning is the stages of stimulation, problem identification, data collection and data processing, verification, and organizing by incorporating the scientific approach that is observing, asking, gathering information, and communicate can improve student learning outcomes of class VII 6 SMP Negeri 01 Bengkulu City. Therefore it confirmed by the improvement of the average score in students observation. Mastery classical at Cycle I, II and III in a row was 69,69\%; $78,78 \%$ and $84,84 \%$ with the percentage of students' learning mastery at least $\geq 80 \%$.
\end{abstract}

\section{Keywords : The Result of Learning, Discovery Learning, Scientific Approach}

\section{PENDAHULUAN}

Matematika merupakan suatu bidang ilmu yang wajib dipelajari disemua jenjang, baik dari jenjang SD, SMP, SMA, bahkan sampai ke jenjang Universitas. Matematika adalah ilmu yang penting dalam dunia pendidikan. Sebagaimana dinyatakan oleh Ali dalam Sundayana (2015: 2) matematika merupakan salah satu komponen dari serangkaian mata pelajaran yang mempunyai peranan penting 
dalam pendidikan. Matematika suatu dasar dari ilmu pengetahuan serta mengembangkan daya pikir manusia yang aktif, kreatif, kritis, dan inovatif.

Hasil wawancara pada tanggal 17 januari 2018, dengan seorang guru matematika VII 6 di SMPN 1 Kota Bengkulu didapat bahwa, kemampuan siswa terbilang cukup rendah, serta metode pembelajaran yang dilaksanakan didalam kelas menggunakan metode diskusi. Pada metode diskusi, guru membentuk kelompok belajar yang terdiri atas 4-6 peserta didik. Namun pada saat penerapan metode ini terlihat bahwa peserta didik masih sulit untuk dikondisikan. Di kelas, media dan sumber belajar siswa kurang, sehingga guru pun kesulitan membuat proses pembelajaran menjadi maksimal. Hal ini terlihat masih ada peserta didik yang malas dalam mencatat pembelajaran di kelas, serta minimnya interaksi antara guru dengan peserta didik pada saat kegiatan diskusi berlangsung. Hal ini berdampak pada hasil belajar mata pelajaran matematika masih terdapat beberapa siswa yang nilainya kurang dari 80 atau masih dibawah rata-rata Kriteria Ketuntasan Minimum (KKM) yaitu $75 \%$ dari 32 siswa. Faktor lainnya yaitu siswa yang baru masuk (siswa kelas VII) bukan lagi siswa pilihan, akan tetapi berdasarkan kebijakan pemerintah menggunakan mekanisme zonasi, sekolah wajib menyerap $90 \%$ dari total daya tampung peserta didik baru yang bertempat tinggal di dekat sekolah. (Permendikbud, Nomor 17 Tahun 2017 tentang PPDB pasal 15)

Banyak siswa yang mengalami kesulitan untuk memahami matematika itu sendiri, kurangnya tingkat kemandirian siswa mengakibatkan hasil belajar matematika kurang maksimal. Hal ini senada dengan apa yang dikatakan oleh guru saat diwawancarai bahwa, tingkat kemandirian dan hasil belajar siswa masih rendah yaitu ditunjukkan dengan presentase beberapa aspek kemandirian dan hasil belajar pada siswa. Penyebab dari rendahnya tingkat kemandirian dan hasil belajar siswa didapatkan bahwa: (1) Kurangnya rasa tanggungjawab dalam diri siswa sehingga mengakibatkan siswa tidak mengerjakan soal. (2) Siswa kurang percaya diri terhadap kemampuan yang dimiliknya, sehingga ada rasa takut ketika maju ke depan kelas dan menjawab pertanyaan dari guru. (3) Guru masih sering menggunakan strategi pembelajaran yang bersifat konvensional, sehingga siswa kurang tertarik dalam mengikuti proses pembelajaran.

Berdasarkan pemikiran di atas, maka guru perlu berupaya meningkatkan kualitas pembelajaran dengan melakukan beberapa usaha perbaikan. Perbaikan tersebut terutama pada proses belajar mengajar dalam rangka meningkatkan hasil belajar peserta didik. Salah satu usaha yang dapat dilakukan adalah menerapkan tipe pembelajaran yang merangsang peserta didik untuk berpartisipasi aktif, dan siswa dapat mengorganisasi materi pembelajaran sendiri dengan bantuan bimbingan guru.

Maka untuk mengatasi permasalahan di atas, penulis menerapkan model Discovery Learning dengan pendekatan Saintifik untuk meningkatkan hasil belajar siswa. Menurut Kurniasih \& Sani (2014: 64) discovery learning didefinisikan sebagai proses pembelajaran yang terjadi bila materi pembelajaran tidak disajikan dalam bentuk finalnya, tetapi diharapkan siswa mengorganisasi sendiri. Selanjutnya, Kurniasih \& Sani (2014: 97) mengungkapkan bahwa discovery adalah menemukan konsep melalui serangkaian data atau informasi yang diperoleh melalui pengamatan atau percobaan.

Kurniasih dan Sani (2016:56) mengatakan bahwa salah satu keunggulan model ini adalah mampu menciptakan suasana belajar aktif dan menyenangkan karena melibatkan media pembelajaran yang dibuat oleh pendidik yang mengakibatkan hasil belajar meningkat.

Berdasarkan pemikiran di atas, maka peneliti tertarik untuk melakukan suatu penelitian yang berjudul : "Penerapan Model Pembelajaran Discovery Learning dengan Pendekatan Saintifik Untuk Meningkatkan 
Hasil Belajar Matematika Siswa Kelas VII 6 di SMP Negeri 01 Kota Bengkulu".

\section{METODE}

Penelitian Tindakan Kelas (PTK) ini terdiri dari 3 siklus. Tiap siklus terdiri dari empat tahap, yaitu perencanaan tindakan (planning), pelaksanaan tindakan (acting), pengamatan tindakan (observing), dan refleksi (reflecting).

Tempat penelitian ini direncanakan akan dilaksanakan di SMP N 01 Kota Bengkulu, dan waktu penelitiannya pada bulan 4 April - 18 mei 2018 pada semester genap tahun 2017/2018. Subjek dalam penelitian ini adalah kelas VII 6 SMP Negeri 01 Kota Bengkulu tahun ajaran 2017/2018. Jumlah siswa kelas VII 6 adalah 33 siswa yang terdiri dari 14 siswa laki-laki dan 19 siswa perempuan. Subjek ini diambil berdasarkan pertimbangan dan persetujuan dari guru matematika di SMP tersebut.

Tes diberikan kepada siswa pada setiap akhir siklus. Tes digunakan untuk mengukur keberhasilan siswa dalam belajar.

Tes hasil belajar yang diperoleh pada setiap siklus dianalisis secara deskriptif untuk mengetahui nilai rata-rata hasil belajar siswa dan persentase ketuntasan belajar klasikal siswa. Rumus yang digunakan dalam perhitungan ini adalah sebagai berikut:

a. Persentase Ketuntasan Belajar Siswa

$$
K B=\frac{N S}{S} \times 100 \%
$$

Sumber: Adaptasi dari Trianto (2011: 241)

Keterangan:

$\mathrm{KB}=$ Ketuntasan belajar

Ns = Banyak siswa yang memperoleh

nilai $\geq 80$

$\mathrm{S}$ = Banyak siswa

Hasil belajar siswa dikatakan berhasil apabila rata-rata hasil belajar siswa mencapai $\geq$ 80 dan persentase ketuntasan belajar siswa $\geq$ $80 \%$. Indikator ini sesuai dengan ketentuan dari sekolah.

\section{HASIL DAN PEMBAHASAN Hasil Penelitian}

Penelitian tindakan kelas ini dilakukan dengan menerapkan model Pembelajaran Discovery Learning dengan Pendekatan Saintifik pada siswa kelas VII 6 SMPN 1 Kota Bengkulu yang dilaksanakan pada tanggal 4 April sampai 18 Mei 2018. Siswa kelas VII 6 berjumlah 33 orang dengan siswa laki-laki sebanyak 14 orang dan perempuan sebanyak 19 orang. Penelitian ini dilaksanakan dalam 3 siklus, setiap siklus terdiri dari empat tahapan, yaitu : 1) Perencanaan, 2) Pelaksanaan, 3) pengamatan, 4) Refleksi. Masing-masing siklus dilaksanakan sebanyak 4 kali pertemuan. Hasil penelitian ini dimulai dari refleksi awal.

Refleksi awal digunakan untuk mengetahui permasalahan-permasalahan yang terjadi di dalam kelas. Sebelum melaksanakan penelitian dengan penerapan model Pembelajaran Discovery Learning dengan Pendekatan Saintifik. Peneliti terlebih dahulu melakukan observasi pembelajaran dan wawancara kepada guru matematika kelas VII 6 SMPN 1 Kota Bengkulu. Observasi pembelajaran dan wawancara dilakukan pada tanggal 17 januari 2018. Berdasarkan hasil wawancara dan observasi pembelajaran di kelas, dapat dikemukakan gambaran umum permasalahan yang dihadapi guru dalam proses pembelajaran matematika di kelas VII 6 SMPN 1 Kota Bengkulu. Diantaranya sebagai berikut:

1. Kemampuan siswa terbilang cukup rendah, serta metode pembelajaran yang dilaksanakan didalam kelas menggunakan metode diskusi. Pada metode diskusi, guru membentuk kelompok belajar yang terdiri atas 4-6 peserta didik. Namun pada saat penerapan metode ini terlihat bahwa peserta didik masih sulit untuk dikondisikan.

2. Media dan sumber belajar siswa kurang, sehingga guru pun kesulitan membuat proses pembelajaran menjadi maksimal. Hal ini terlihat masih ada peserta didik yang malas dalam mencatat pembelajaran di kelas.

3. Serta minimnya interaksi antara guru dengan peserta didik pada saat kegiatan 
diskusi berlangsung. Hal ini berdampak pada hasil belajar mata pelajaran matematika masih terdapat beberapa siswa yang nilainya kurang dari 80 atau masih dibawah rata-rata Kriteria Ketuntasan Minimum (KKM) yaitu 75\% dari 33 siswa.

4. Adanya permasalahan yang terjadi pada saat refleksi awal mendorong peneliti untuk menerapkan model Pembelajaran Discovery Learning dengan Pendekatan Saintifik di kelas VII 6 SMPN 1 Kota Bengkulu untuk meningkatkan hasil belajar dan aktivitas siswa.

Refleksi siklus I dilakukan setelah peneliti melakukan 3 kali pertemuan dalam proses pembelajaran yang menggunakan model Pembelajaran Discovery Learning dengan Saintifik dan 1 kali tes siklus. Adapun data hasil belajar dari tes siklus I dibuat menggunakan microsoft excel dengan rumus rata-rata dan dapat dilihat pada tabel dibawah ini :

Tabel 1. Hasil Belajar Tes Siklus I

\begin{tabular}{|l|c|}
\hline \multicolumn{1}{|c|}{ Deskripsi } & Nilai \\
\hline Maksimum & 85 \\
\hline Minimum & 25 \\
\hline Rata-rata & 75,85 \\
\hline Median & 80 \\
\hline Persentase & $69,69 \%$ \\
Ketuntasan & \\
Klasikal & \\
\hline Keterangan & Belum Tuntas \\
\hline
\end{tabular}

(Sumber : Hasil Penelitian )

Berdasarkan hasil tes siklus I, nilai tertinggi adalah 85 dan nilai terendah adalah 25 , dengan nilai rata-rata yang diperoleh dari 33 orang siswa yaitu 75,85. Persentase ketuntasan belajar klasikal $69,69 \%$ dimana terdapat 23 orang siswa yang memperoleh nilai $\geq 80$ dan 10 orang siswa yang memperoleh nilai < 80. Hal ini menunjukkan bahwa kriteria keberhasilan belum tercapai.
Refleksi siklus II dilakukan setelah peneliti melakukan 3 kali pertemuan dalam proses pembelajaran yang menggunakan model Pembelajaran Discovery Learning dengan Saintifik dan 1 kali tes siklus. Adapun hasil belajar dari tes siklus II dibuat menggunakan microsoft excel dengan rumus rata-rata dan dapat dilihat pada tabel dibawah ini:

Tabel 2. Hasil Belajar Tes Sisklus II

\begin{tabular}{|l|c|}
\hline \multicolumn{1}{|c|}{ Deskripsi } & Nilai \\
\hline Maksimum & 93 \\
\hline Minimum & 42 \\
\hline Rata-rata & 77,33 \\
\hline Median & 81 \\
\hline Persentase & $78,78 \%$ \\
Ketuntasan & \\
Klasikal & \\
\hline \multicolumn{1}{|c|}{ Keterangan } & Belum Tuntas \\
\hline
\end{tabular}

(Sumber : Hasil Penelitian)

Berdasarkan hasil tes siklus II, nilai tertinggi adalah 93 dan nilai terendah adalah 42 , dengan nilai rata-rata yang diperoleh dari 33 orang siswa yaitu 77,33. Persentase ketuntasan belajar klasikal $78,78 \%$ dimana terdapat 26 orang siswa yang memperoleh nilai $\geq 80$ dan 7 orang siswa yang memperoleh nilai $<$ 80. Hal ini menunjukkan bahwa kriteria keberhasilan belum tercapai.

Refleksi siklus III dilakukan setelah peneliti melakukan 3 kali pertemuan dalam proses pembelajaran yang menggunakan model Pembelajaran Discovery Learning dengan Saintifik dan 1 kali tes siklus. Adapun hasil akhir dari siklus III dibuat menggunakan microsoft excel dengan rumus rata-rata dan dapat dilihat pada tabel dibawah ini :

Tabel 3. Hasil Belajar Tes Sisklus III

\begin{tabular}{|l|c|}
\hline \multicolumn{1}{|c|}{ Deskripsi } & Nilai \\
\hline Maksimum & 100 \\
\hline Minimum & 50 \\
\hline
\end{tabular}




\begin{tabular}{|l|c|}
\hline Rata-rata & 82,36 \\
\hline Median & 84 \\
\hline Persentase & $84,84 \%$ \\
Ketuntasan & \\
Klasikal & \\
\hline \multicolumn{1}{|c|}{ Keterangan } & Tuntas \\
\hline
\end{tabular}

(Sumber : Hasil Penelitian)

Berdasarkan hasil tes siklus III, nilai tertinggi adalah 100 dan nilai terendah adalah 50, dengan nilai rata-rata yang diperoleh dari 33 orang siswa yaitu 82,36. Persentase ketuntasan belajar klasikal $84,84 \%$ dimana terdapat 28 orang siswa yang memperoleh nilai $\geq 80$ dan 5 orang siswa yang memperoleh nilai $<$ 80. Hal ini menunjukkan bahwa kriteria keberhasilan tercapai dan penelitian dihentikan.

Hasil belajar siswa pada ranah pengetahuan diperoleh berdasarkan nilai tes akhir siswa yaitu tes akhir setiap siklus. Tes hasil belajar dilakukan untuk melihat keberhasilan guru dalam menerapkan model Pembelajaran Discovery Learning dengan Pendekatan Saintifik dalam pembelajaran. Berdasarkan analisis terhadap hasil belajar siswa pada tes siklus secara individu dengan diolah menggunakan Microsoft Excel, maka diperoleh hasil sebagai berikut :

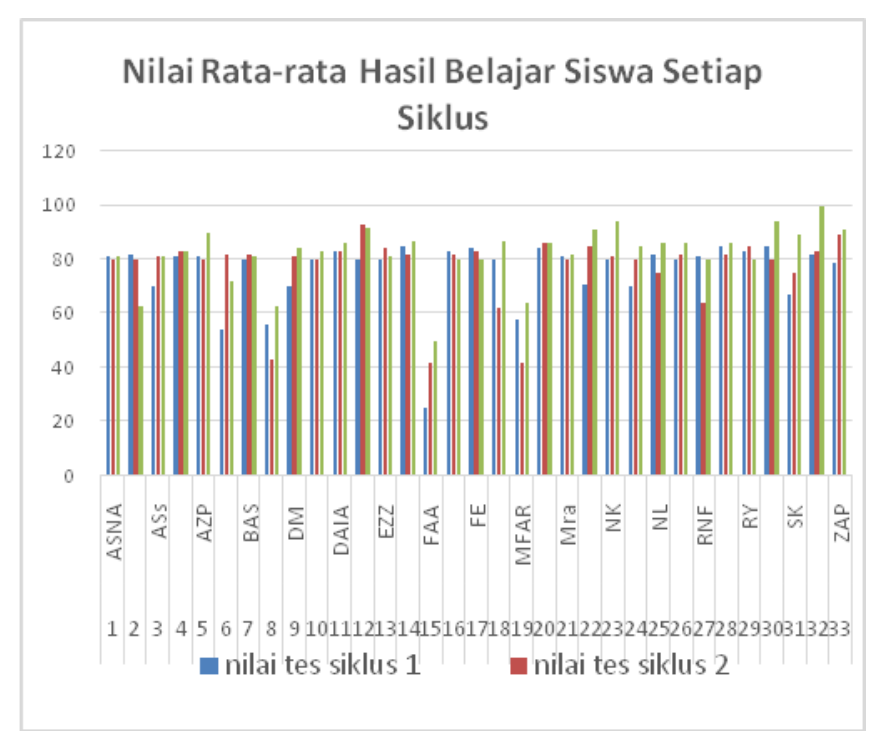

Gambar 1 : Grafik Nilai Rata-rata Hasil Belajar Siswa Setiap Siklus
Berdasarkan gambar grafik 1 dapat dilihat bahwa perkembangan nilai akhir siswa secara individu tidak selalu meningkat disetiap siklusnya. Nilai siswa yang meningkat disetiap siklusnya ada 14 orang. Guru sudah mencoba menegur, memotivasi, memberikan soal latihan dan membimbing secara khusus dalam pengerjaannya serta memberikan nasihat, tetapi siswa tersebut masih tetap tak mengacuhkan nasihat dari guru, sehingga mengakibatkan nilai tes hasil belajar mereka belum mencapai ketuntasan.

Pada siklus I nilai rata-rata siswa belum mencapai kriteria keberhasilan yang diharapkan. Terdapat 10 orang siswa yang tidak tuntas dikarenakan siswa masih belum memahami masalah yang diberikan.

Pada siklus II nilai rata-rata siswa mengalami peningkatan. Terdapat 6 siswa yang mendapatkan nilai < 80. Dari data hasil tes siklus II menunjukkan bahwa siswa mengalami kesulitan dalam menjawab soal yang merubah satuan Luas. Siswa masih keliru dalam menghitung persamaan luas are dengan $\mathrm{m}^{2}$ banyak fungsi yang mungkin dari dua himpunan. Untuk soal 1 dan 4 hampir semua siswa sudah mampu menawab, meskipun ada beberapa yang masih mengalami kekeliruan.

Pada siklus III nilai rata-rata siswa mengalami peningkatan dari siklus II. Terdapat 5 siswa yang tidak tuntas dan mendapatkan nilai < 80. Dari data hasil tes siklus III menunjukkan bahwa siswa mengalami kesulitan dalam menjawab soal. Siswa masih keliru dalam melakukan perhitungan matematika dan masih kurang teliti dalam memahami soal. Meskipun ada beberapa yang masih mengalami kekeliruan tetapi semua jawaban dari siswa sudah mendekati sempurna.

Berdasarkan hasil tes siklus I, siklus II, dan siklus III setelah diterapkan model Pembelajaran Discovery Learning dengan pendekatana Saintifik, hasil belajar siswa mengalami peningkatan dengan rata-rata hasil 
belajar siswa 82,36 pada siklus III dan ketuntasan belajar klasikal siswa mencapai $84,84 \%$. Hal ini sesuai dengan pendapat Sudjana (2006:22) yang menyatakan hasil belajar adalah kemampuan-kemampuan (termasuk kemampuan kognitif) yang dimiliki siswa setelah menerima pengalaman belajar. Berdasarkan Kurikulum Tingkat Satuan Pendidikan di SMP Negeri 1 Kota Bengkulu untuk:

1. Individu: jika siswa mendapat nilai sesuai dengan Kriteria Ketuntasan Minimal (KKM) yaitu $\geq 80$ untuk tes pada setiap akhir siklusnya, sedangkan dalam penelitian ini rata-rata nilai akhir siswa untuk mencapai kriteria keberhasilan dalam penelitian yaitu rata-rata nilai akhir siswa $\geq 80$.

2. Klasikal: jika $80 \%$ dari jumlah siswa memperoleh nilai $\mathrm{KKM} \geq 80$ untuk tes pada setiap akhir siklusnya sesuai dengan kriteria tingkat keberhasilan belajar siswa.

Tabel 4. Tabel Perbandingan Hasil Belajar Secara Klasikal Setiap Siklus

\begin{tabular}{|c|c|c|c|c|}
\hline Siklus & $\begin{array}{l}\text { Nilai } \\
\text { rata- } \\
\text { rata }\end{array}$ & $\begin{array}{l}\text { Jumlah } \\
\text { siswa } \\
\text { yang } \\
\text { tuntas }\end{array}$ & $\begin{array}{l}\text { Ketuntasan } \\
\text { belajar } \\
\text { klasikal }\end{array}$ & Keterangan \\
\hline I & 75,84 & 23 & $69,69 \%$ & $\begin{array}{c}\text { Belum } \\
\text { tercapai }\end{array}$ \\
\hline II & 77,33 & 26 & $78,78 \%$ & $\begin{array}{c}\text { Belum } \\
\text { tercapai }\end{array}$ \\
\hline III & 82,36 & 28 & $84,84 \%$ & Tercapai \\
\hline
\end{tabular}

(Sumber : Hasil Penelitian)

Berdasarkan tabel di atas, dapat dilihat bahwa terjadi peningkatan hasil belajar siswa secara berturut-turut dari siklus ke I sampai siklus ke III, yaitu nilai rata-rata siswa pada siklus ke I sebesar 75,84 meningkat disiklus II sebesar 77,33 dan meningkat ke siklus ke III sebesar 82,36. Persentase ketuntasan belajar pada grafik di atas mengalami peningkatan pada setiap siklus. Pada siklus I yaitu $69,69 \%$, hal ini berarti hanya 23 orang siswa yang memperoleh nilai $\geq 80$. Dan pada siklus II meningkat menjadi $78,78 \%$, yang berarti 26 orang siswa yang memperoleh nilai $\geq 80$, karena belum memenuhi indikator keberhasilan maka dilanjutkan pada siklus III. Pada siklus III ketuntasan belajar klasikal siswa meningkat hingga mencapai $84,84 \%$, yang berarti 28 orang siswa telah mencapai kriteria ketuntasan minimal yaitu $\geq 80$. Hal ini berarti pada siklus III ketuntasan belajar klasikal siswa sudah mencapai kriteria keberhasilan yaitu $\geq 80 \%$.

Berdasarkan data tersebut menunjukkan bahwa penerapan model Pembelajaran Discovery Learning dengan pendekatan Saintifik dapat meningkatkan hasil belajar matematika siswa kelas VII SMP Negeri 1 Kota Bengkulu.

\section{PEMBAHASAN}

\section{Analisis Cara-Cara Peningkatan Hasil Belajar}

Pencapaian hasil belajar siswa dari siklus I sampai siklus III pada kelas VII 6 SMP N 1 Kota Bengkulu dengan penerapan model discovery learning dengan pendekatan saintifik yang dilakukan mengalami peningkatan ditinjau dari nilai rata-rata siswa maupun ketuntasan belajar klasikalnya.

Gambar 1 dapat dilihat bahwa 14 orang siswa yang selalu meningkat tiap siklusnya, 12 orang siswa yang nilainya turun pada tes siklus II, dan 7 orang siswa yang nilainya turun pada tes siklus III. Selama tiga siklus, ada 3 orang siswa yang nilainya belum pernah mencapai KKM, yaitu 80 dengan rincian: 1) FAA dengan nilai siklus I yaitu 25, siklus II nilainya 42, dan siklus III nilainya 50, dan 2) BIRTH dengan nilai siklus I adalah 56, nilai siklus II 43, dan siklus III nilainya 63, dan 3) MFAR dengan nilai siklus I adalah 58, nilai siklus II adalah 42 dan siklus III nilainya 64.

FAA merupakan salah satu dari tiga siswa yang tidak pernah mencapai KKM pada setiap siklus. Siklus I nilainya hanya 25 , dikarenakan FAA hanya mengisi jawaban langsung tanpa menuliskan cara penyelesaian dan jawabannya 
pun hanya sedikit yang mendekati kebenaran. FAA merupakan siswa yang paling sering ribut dan usil terhadap teman-temannya. Dalam diskusi kelompok FAA sulit untuk diatur dan tenang. Tindakan yang dilakukan guru terhadap FAA adalah memberi arahan dan perhatian lebih untuk mengikuti kegiatan pembelajaran dan diskusi kelompok dengan tenang dan serius. Tindakan ini berhasil dilakukan terlihat pada gambar 4.57 FAA selalu mengalami peningkatan setiap siklusnya dan pada siklus III tetapi nilai FAA tidak pernah mencapai KKM.

MFAR juga merupakan salah satu siswa yang tidak pernah mencapai KKM pada setiap siklus, menurut informasi dari siswa di kelas VII 6 MFAR merupakan siswa yang kurang dari segi akademik, MFAR juga di kelas jarang sekali aktif membantu temannya dalam mengerjakan kelompok. MFAR selalu asik sendiri namun tidak mengganggu proses pembelajaran. Tindakan yang dilakukan guru tehadap MFAR dengan memberikan perhatian lebih dan menjelaskan materi secara pelanpelan kepada MFAR juga tidak berhasil, MFAR hanya mengerti dan paham pada saat itu saja, untuk keesokannya MFAR kembali tidak dapat menyelesaikan soal.

BIRTH merupakan salah satu siswa yang tidak pernah mencapai KKM pada setiap siklus. BIRTH merupakan siswa yang pendiam, ini terlihat dia semi aktif dalam hal bekerja sama dengan kelompoknya. Namun BIRTH adalah siswa yang selalu memperhatikan guru menjelaskan materi dan BIRTH termasuk siswa yang tidak mengganggu pembelajaran. Guru sering memberikan nasehat dan sering menyuruh BIRTH untuk aktif dalam kegiatan. Meskipun demikian, nilai BIRTH mengalami naik turun pada setiap siklus dan pada siklus III mencapai batas maksimum usahanya yaitu 63 .

Gambar 1 juga terlihat bahwa pada tes hasil belajar siklus II ada 12 orang siswa yang nilainya menurun, diantaranya yaitu siswa yang berinisial ASNA, AZP, BIRTH, FA, FAP, FE, GBR, MFAR, MRa, NL, RNF, dan SPA. Mereka mengerjakan soal pada tes siklus II dengan berbeda-beda kesalahannya satu sama lain, keumuman mereka yaitu sering menganggap remeh persoalan sehingga mereka lupa menuliskan satuan dan banyak dari mereka yang terburu-buru menyelesaikan soal karena kehabisan waktu.

Melihat kondisi tersebut, guru melakukan perbaikan tindakan untuk tes selanjutnya. Guru kembali memotivasi siswa pada pertemuan pertama siklus III untuk lebih berhati-hati dan teliti dalam menghitung angka dan menjawab soal, guru juga mengumumkan hasil tes belajar siswa siklus II tersebut, guru menekankan kepada siswa untuk selanjutnya lebih memperhatikan waktu pengerjaan.

Guru juga mengingatkan siswa pada setiap kali mengerjakan soal pada setiap tes akhir untuk membuat apa yang diketahui dan ditanyakan dari soal dan diakhir setiap jawaban diberikan kesimpulan, jika tidak dibuat maka tidak akan mendapatkan skor maksimal pada setiap soal, itulah yang membuat nilai menjadi rendah. Tindakan ini berhasil dilakukan 28 siswa sudah berhasil mendapatkan nilai diatas KKM pada tes akhir siklus III. Seluruh siswa sudah membuat apa yang diketahui dan ditanyakan dan juga sudah membuat kesimpulan akhir pada setiap jawaban soal yang ada.

Sesuai dengan pencapaian dan berbagai upaya untuk memperbaiki hal-hal yang belum tercapai pada setiap siklus, maka didapatkan cara-cara meningkatkan hasil belajar pada model pembelajaran discovery learning dengan pendekatan saintifik :

a. Siswa diberikan masalah dari berbagai disiplin ilmu yang berkaitan dengan masalah yang pernah dikenal siswa sebelumnya, baik dalam kehidupan seharihari ataupun masalah dalam bidang Matematika.

b. Memberikan kesempatan kepada siswa untuk berfikir dan membiarkan mereka berpendapat dengan bebas, guna untuk meningkatkan kepercayaan diri mereka. Kemudian barulah guru meluruskan apabila ada kekeliruan.

c. Memberikan bimbingan tambahan kepada siswa yang belum tuntas pada tiap siklus, 
dengan cara mendampingi siswa dalam menyelesaikan soal LKPD.

d. Memberikan motivasi kepada siswa yang berkemampuan rendah dan kurang aktif.

Mengecek pemahaman siswa terhadap materi dengan memberikan kegiatan tambahan sebelum masuk ke materi, agar siswa lebih siap, berani dalam berpendapat dan tidak takut untuk salah, sehingga mereka belajar dari kesalahannya tersebut.

\section{PENUTUP}

\section{Simpulan}

Berdasarkan hasil penelitian dan pembahasan dengan menerapkan model Pembelajaran Discovery Learning dengan pendekatan Saintifik di kelas VII 6 SMPN 1 Kota Bengkulu, dapat di ambil kesimpulan sebagai berikut:

Meningkatkan hasil belajar siswa, dapat dilihat dari nilai rata-rata dan ketuntasan belajar siswa pada setiap siklus. Pada siklus I, nilai rata-rata hasil belajar siswa 75,84 dengan persentase ketuntasan belajar klasikal $69,69 \%$. Pada siklus II, nilai rata-rata hasil belajar siswa menjadi 77,33 dengan persentase ketuntasan belajar klasikal sebesar 78,78\%. Pada siklus III, nilai rata-rata hasil belajar siswa 82,36. dengan persentase ketuntasan belajar klasikal sebesar $84,84 \%$.

\section{Saran}

Berdasarkan penelitian yang telah dilakukan maka peneliti memberikan beberapa saran, yaitu:

1. Guru harus mampu mengelola kelas dengan baik dan menjadi fasilisator yang baik. Agar siswa tetap fokus dalam belajar, siswa dibimbing saat mengerjakan LKPD dan mengajak siswa berdiskusi dan memastikan bahwa semua anggota kelompok itu bekerja pada setiap tahap.
2. Guru mengkondisikan siswa untuk disiplin dengan menasehati dan menegur serta langsung memberikan banyak kesempatan kepada siswa yang ribut untuk terlibat aktif dalam kegiatan-kegiatan dari guru di depan kelas.

Setiap kegiatan dan tahap dalam pembelajaran diberikan petunjuk lengkap dan jelas agar siswa tidak selalu bertanya kepada guru tentang apa yang harus dilakukan.

\section{DAFTAR PUSTAKA}

Kurniasih, Sani,. (2014). Implementasi Kurikulum 2013 Konsep \& Penerapan. Surabaya: Kata Pena.

Prayitno, Panduan Kegiatan Pengawasan Bimbingan dan Konseling Di Sekolah, (Jakarta:PT.Rineka Cipta,2001)

Rusman,(2012). Model-Model Pembelajaran. Depok : PT Rajagrafindo Persada

Rosarina, Gina dkk. (2016). Penerapan Model Discovery Learning untuk Meningkatan

Sundayana. (2015). Statistika Penelitian Pendidikan. Bandung: Alfabeta. 